\title{
PENERAPAN MODEL PEMBELAJARAN SNOWBALL THROWING UNTUK MENINGKATKAN HASIL BELAJAR SISWA KELAS IV SD KARTIKA I-1
}

\author{
Ester Julinda Simarmata
}

Surel: ejulinda@ymail.com

\begin{abstract}
ABSTRAK
Penelitian ini bertujuan untuk meningkatan hasil belajar siswa melalui model pembelajaran Snowball Throwing materi Koperasi dan Kesejahteraan Masyarakat. Berdasarkan analisis data diperoleh hasil belajar siswa siklus I dan siklus II diketahui bahwa nilai rata-rata tes evaluasi dari 69 menjadi 79,1. Ketuntasan siswa dalam belajar IPS melalui model pembelajaran Snowball Throwing materi Koperasi dan Kesejahteraan Masyarakat terjadi peningkatan. Hal ini dapat dilihat dari persentase ketuntasan belajar siswa pada siklus I sebesar 54,1\%, sedangkan pada siklus II ketuntasan belajar siswa sebesar $87,50 \%$. Dengan demikian, peningkatan yang terjadi antara ketuntasan belajar siswa pada siklus I dengan siklus II sebesar 33,4\%.
\end{abstract}

Kata Kunci : Model Pembelajaran, Snowball Throwing, Hasil Belajar

\section{PENDAHULUAN}

Tujuan utama dengan diselenggarakannya proses belajar adalah demi tercapainya keberhasilan siswa dalam belajar, baik itu suatu pelajaran tertentu maupun pendidikan pada umumnya. Dalam upaya untuk mewujudkan fungsi pendidikan sebagai wahana sumber daya manusia, perlu dikembangkan iklim belajar mengajar yang kondusif bagi berkembangnya potensi kreatif siswa.

IPS merupakan salah satu mata pelajaran yang diberikan mulai dari SD. IPS mengkaji seperangkat peristiwa, fakta, konsep, dan generalisasi yang berkaitan dengan isu sosial. Melalui mata pelajaran IPS, peserta didik diarahkan untuk dapat menjadi warga negara Indonesia yang demokratis, dan bertanggung jawab, serta warga dunia yang cinta damai. Pengajaran IPS pada hakikatnya adalah pengajaran mengenai interaksi aspek-aspek kehidupan manusia di masyarakat atau merupakan proses pengajaran yang memadukan berbagai pengetahuan sosial.

Mata pelajaran IPS adalah salah satu mata pelajaran wajib yang diajarkan kepada siswa sekolah dasar. IPS mempunyai peranan yang penting bagi siswa dalam memposisikan dirinya dalam berinteraksi baik dalam lingkungan keluarga, sekolah, dan masyarakat. IPS berperan sebagai pendorong untuk saling pengertian dan persaudaraan antar umat manusia, selain itu juga memusatkan perhatiannya pada hubungan antar manusia dan pemahaman sosial. Dengan kata lain IPS mendorong kepekaan siswa terhadap hidup dan

Dosen Universitas Katolik St. Thomas Medan 
kehidupan sosial (Hidayati, dkk., 2008:1-2).

Berdasarkan pengamatan awal yang dilakukan terhadap aktivitas pembelajaran IPS pada siswa kelas IV, guru dalam hal ini belum memanfaatkan penggunaan variasi model pembelajaran. Dalam hal ini model pembelajaran Snowbal Throwing belum digunakan guru dalam meningkatkan prestasi belajar IPS pada siswa kelas IV SD Swasta Kartika I - 1. Untuk mengatasi semua permasalahan di atas dapat dilakukan dengan memberikan model pembelajaran yang variatif pada siswa. Salah satu model pembelajaran yang dapat digunakan sebagai model pembelajaran yang variatif adalah model pembelajaran Snowball Throwing. Penggunaan model Snowball Throwing memiliki kelebihan diantaranya melatih kesiapan siswa dan saling memberikan pengetahuan (Hamdan, 2012).

Prinsipnya model pembelajaran Snowball Throwing membagi siswa menjadi beberapa kelompok kecil. Setiap kelompok mempunyai satu orang ketua yang akan menjelaskan materi yang diberikan guru kepada anggota kelompoknya. Lalu tiap anak menulis satu pertanyaan dan dilempar seperti bola salju kepada siswa lain. Selain itu pembagian kelompok ini bertujuan agar siswa dapat berkolaborasi dengan teman, lingkungan, dan guru, sehingga diharapkan setiap siswa akan siap dalam kegiatan pembelajaran dan merangsang siswa untuk belajar.

Dari uraian tersebut, peneliti merasa perlu meneliti tentang "Penerapan Model Pembelajaran Snowball Throwing untuk Meningkatkan Hasil Belajar Siswa Kelas IV SD Swasta Kartika I - 1".

Prinsipnya model pembelajaran Snowball Throwing membagi siswa menjadi beberapa kelompok kecil. Setiap kelompok mempunyai satu orang ketua yang akan menjelaskan materi yang diberikan guru kepada anggota kelompoknya. Lalu tiap anak menulis satu pertanyaan dan dilempar seperti bola salju kepada siswa lain. Selain itu pembagian kelompok ini bertujuan agar siswa dapat berkolaborasi dengan teman, lingkungan, dan guru, sehingga diharapkan setiap siswa akan siap dalam kegiatan pembelajaran dan merangsang siswa untuk belajar.

Salah satu pendekatan dalam pembelajaran IPS dan sekaligus menjadi tugas guru pada tingkat pendidikan dasar adalah menerjemahkan materi sulit, menjadi mudah atau materi yang bersifat abstrak menjadi konkret. Program pembelajaran IPS menekankan harus mampu memberikan pengalamanpengalaman belajar yang berorientasi pada aktivitas belajar peserta didik. Pelibatan peserta didik secara penuh dalam serangkaian aktivitas dan pengalaman belajar mampu memberikan kesempatan yang luas pada peserta didik untuk terlibat 
dalam proses memecah masalah dalam lingkungan belajar yang dibuat sebagaimana realitas yang sesungguhnya. Kurikulum 1994 memberikan anjuran umum bahwa pelaksanaan proses pembelajaran hendaknya para guru menerapkan prinsip belajar aktif. Maksudnya bahwa pembelajaran di kelas hendaknya melibatkan siswa, baik secara fisik, mental (pemikiran dan perasaan), dan sosial sesuai denga penilaian, dan saran yang digunakan dalam proses belajar mengajar dapat ditentukan oleh guru sesuai dengan kebutuhan dan kemampuan.

Tujuan dari penelitian ini adalah penggunaan metode pembelajaran Snowbal Throwing untuk meningkatkan hasil belajar IPS siswa.

\section{METODE PENELITIAN}

Penelitian ini dilaksanakan di SD Swasta Kartika I-1. Waktu penelitian dilaksanakan pada Semester Genap Tahun Ajaran 2015/2016. Subjek penelitian ini adalah semua siswa kelas IV SD Swasta Kartika I-1 berjumlah 24 siswa. Objek dalam penelitian ini adalah meningkatkan hasil belajar siswa dalam memahami materi Koperasi dan Kesejahteraan Masyarakat dan alternatif tindakan yang diberikan sebagai upaya untuk meningkatkan hasil belajar IPS siswa kelas IV SD Swasta Kartika I-1.

Penelitian ini dilaksanakan dalam siklus tindakan, yang mana pada siklus tersebut siklus terdiri dari empat langkah (Suharsimi Arikunto dkk, 2008: 6) sebagai berikut: (1) perencanaan yaitu merumuskan masalah, menentukan tujuan dan metode penelitian serta membuat rencana tindakan, (2) tindakan yang dilakukan sebagai upaya perubahan yang dilakukan, (3) observasi, dilakukan secara sistematis untuk mengamati hasil atau dampak tindakan terhadap proses belajar mengajar, (4) refleksi, yaitu mengkaji dan mempertimbangkan hasil dampak tindakan yang dilakukan.

Teknik pengumpulan data dilakukan melalui tes, observasi dan catatan lapangan. Tes digunakan untuk mengetahui sejauh mana tingkat penguasaan siswa terhadap materi koperasi dan kesejahteraan masyarakat, dan observasi berupa pengamatan terhadap kegiatan siswa dan perubahan yang terjadi pada saat dilakukannya pemberian tindakan dalam pernyataan yang dicatat pada saat pembelajaran berlangsung.

Teknik analisis data dilakukan secara kuantitatif berdasarkan tes kemampuan dan observasi.

\section{HASIL DAN PEMBAHASAN}

Hasil penelitian yang disajikan meliputi persentase ketuntasan belajar selama 2 (dua) siklus.

Setelah melakukan apersepsi guru kemudian menyampaikan informasi materi serta informasi tujuan. Selanjutnya guru mulai dengan kegiatan inti, yaitu siswa 
mengamati media gambar dan melakukan tanya jawab dengan guru mengenai materi Koperasi dan Kesejahteraan Masyarakat. Kemudian membentuk siswa dalam kelompok yang terdiri dari 4 siswa. Setelah pembagian kelompok usai, guru membagikan lembar kegiatan siswa.

Siswa bersama kelompok berdiskusi untuk membuat pertanyaan seputar makna kesatuan wilayah Indonesia dari segi politik, sosial budaya, ekonomi, dan pertahanankeamanan dan menulisnya pertanyaan kelompok di dalam LKS. Setelah kelompok menyelesaikan kegiatan membuat pertanyaan, kemudian siswa menuliskan pertanyaan tersebut dalam sebuah kertas dan meremasremas kertas tersebut hingga menyerupai bola salju. Dilanjutkan melemparkan pertanyaan dalam kertas yang telah dibentuk menyerupai bola salju kepada siswa/ kelompok lain. Siswa/ Kelompok lain yang mendapat pertanyaan dari kelompok lain segera menjawab pertanyaan tersebut. Guru membantu siswa dengan memberi bimbingan saat siswa menjawab pertanyaan. Selanjutnya guru memberikan refleksi serta umpan balik kepada siswa, sekaligus bertanya tentang tanggapan siswa selama kegiatan pembelajaran berlangsung, tanggapan ini kemudian dicatat oleh guru. Sebelum mengakhiri pelajaran guru memberikan tindak lanjut berupa perintah membaca buku mengenai materi dan untuk berlatih membuat pertanyaan yang baik.

Dari hasil pelaksanaan siklus I penerapan model pembelajaran Snowball Throwing pada pembelajaran IPS materi Koperasi dan Kesejahteraan Masyarakat di kelas IV SD Swasta Kartika I-1 diperoleh hasil penilaian tes hasil belajar yang telah dilakukan. Hasil yang didapatkan siswa mengalami peningkatan dengan hasil pra siklus.

Dari data yang diperoleh dapat diketahui bahwa dengan penerapan model pembelajaran Snowball Throwing pada pelajaran IPS materi Koperasi dan Kesejahteraan Masyarakat pada siklus I diperoleh nilai rata- rata siswa yaitu 69. Dari 24 jumlah siswa sebanyak 11 siswa yang belum tuntas karena nilai yang diperoleh belum mencapai KKM yang diharapkan. Nilai KKM yang ditentukan sekolah yaitu 75 sehingga persentase ketuntasan yang diperoleh hanya sebesar $54,1 \%$, hal ini masih jauh dari kriteria keberhasilan yang diharapkan, karena belum mencapai KKM yang dietapkan sekolah.

Untuk mencapai tingkat persentase ketuntasan belajar klasikal tersebut direncanakan yaitu minimal $85 \%$, maka terdapat minimal $30,9 \%$ dari jumlah siswa yang mengikuti tes sebagai kekurangannya. Hal ini akan menjadi perhatian sebagai bahan refleksi untuk tindak lanjut ke siklus II. 
Tabel 3. Rincian Hasil Belajar Siswa Setelah Penerpan Model Snowball Throwing

\begin{tabular}{|c|c|c|}
\hline No & Nilai & $\begin{array}{c}\text { Jumlah } \\
\text { Siswa }\end{array}$ \\
\hline 1 & $>75$ & 21 \\
\hline 2 & $<75$ & 3 \\
\hline
\end{tabular}

Pada hasil belajar siswa siklus siklus II ini, terdapat 21 siswa yang sudah tuntas KKM sebesar 75 (87,5\%). Namun masih ada juga siswa yang belum tuntas hasil belajarnya yaitu 3 siswa (12,5\%). Hal ini dimungkinkan kurangnya konsentrasi siswa dalam mengerjakan soal tes. Namun secara keseluruhan, hasil belajar siswa pada siklus II sudah memenuhi standar ketuntatasan persentase kelas sebesar $87,5 \%$ yang mengalami peningkatan dari siklus I sebesar 33,4\% (87,5\% - 54,1\%).

Beberapa kegiatan yang dilakukan peneliti dan rekan sejawat dalam merefleksi siklus II, di antaranya adalah sebagai berikut:

1. Pelaksanaan model pembelajaran snowball throwing tentang Koperasi dan Kesejahteraan Masyarakat pada siklus II lebih daripada siklus I. Semua indikator serta tujuan pembelajaran sedah terpenuhi. Guru sudah merencanakan RPP dengan baik dan menampakkan semua indikator dalam pelaksanaan pembelajaran.

2. Pada saat berdiskusi atau bekerja kelompok untuk membuat pertanyaan sebagian besar siswa sudah dapat melaksanakannya dengan baik serta hampir semua siswa terlihat aktif bekerjasama di dalam kelompoknya.

3. Sebagian besar siswa terlihat antusias dalam melemparkan serta menjawabpertanyaan kepada temannya/kelompok lain.

4. Siswa terlihat seakin kreatif dalam membuat pertanyaan.

5. Berdasarkan hasil belajar siswa menunjukkan bahwa kemampuan pemahaman siswa mengalami peningkatan.

Dengan demikian, banyaknya siswa yang tuntas individual adalah 21 siswa, dengan kata lain ketuntasan belajar klasikalnya mencapai 87,50\%. Tingkat persentase ketuntasan belajar klasikal direncanakan minimal $85 \%$ dari jumlah siswa yang mengikuti tes. Berdasarkan hasil tes evaluasi pada siklus II, hasil belajar siswa mengalami peningkatan yang signifikan sehingga dapat disimpulkan bahwa pelaksanaan pembelajaran pada siklus II telah tercapai dan memenuhi indikator keberhasilan dan tidak perlu dilanjutkan pada siklus berikutnya.

Berdasarkan hasil penelitian yang telah dilaksanakan pembahasan mata pelajaran IPS materi Koperasi dan Kesejahteraan Masyarakat melalui model pemelajaran snowball throwing pada siswa kelas IV SD Swasta Kartika I-1 ketuntasan dari penilaian hasil tes belajar siswa pada 
siklus I menunjukkan nilai rata-rata kelas yaitu 69 dengan siswa yang tuntas yaitu sebanyak 13 siswa dari 24 jumlah siswa kelas IV sehingga persentase yang diperoleh sebesar $54,1 \%$ karena siswa kurang aktif dalam berdiskusi dan kurang memperhatikan pembelajaran sehingga nilai yang dipeoleh siswa masih banyak yang belum mencapai KKM yaitu 75. Pada perbaikan siklus II siswa mulai terbiasa menggunakan model pembelajaran snowball throwing sehingga hasil belajar siswa meningkat. Terlihat dari kenaikan nilai rata-rata kelas pada siklus II yaitu 79,1 yang sudah mencapai KKM dengan siswa yang tuntas yaitu 21 dari 24 jumlah siswa kelas IV. Sehingga persentase dari penilaian tes hasil belajar pada siklus II memperoleh 87,5\%.

Pemaparan di atas menunjukkan bahwa model snowball throwing dapat meningkatkan hasil belajar siswa dan aktif dalam proses pembelajaran sehingga siswa dapat mencapai KKM dalam mata pelajaran IPS materi Koperasi dan Kesejahteraan Masyarakat. Dari hasil penelitian yang dilakukan dapat diketahui bahwa penelitian telah mengalami keberhasilan.

\section{SIMPULAN}

Berdasarkan hasil analisis terhadap data penelitian, maka dapat dikemukakan kesimpulan:

1. Hasil belajar siswa siklus I dan siklus II diketahui bahwa nilai rata-rata tes evaluasi dari 69 menjadi 79,1, skor terendah dari 50 menjadi 60 dan skor tertinggi dari 80 menjadi 96 .

2. Persentase ketuntasan belajar siswa pada siklus I sebesar $54,1 \%$, sedangkan pada siklus II ketuntasan belajar siswa sebesar 87,50\%. Dengan demikian, peningkatan yang terjadi antara ketuntasan belajar siswa pada siklus I dengan siklus II sebesar $33,4 \%$.

Berdasarkan hasil penelitian, simpulan, dan implikasi penelitian, maka dikemukakan saran-saran sebagai berikut:

1. Guru dapat menerapkan model pembelajaran Snowball Throwing dalam rangka meningkatkan kualitas pembelajaran.

2. Siswa menjadi lebih berani untuk bertanya apabila masih ada yang tidak dipahami, lebih berani menjawab pertanyaan, dan berani ke depan kelas untuk mengerjakan soal yang diberikan.

3. Di kelas IV SD Swasta Kartika I1, model pembelajaran Snowball Throwing yang telah dilaksanakan dapat meningkatkan hasil belajar siswa terhadap pembelajaran IPS.

4. Jika diterapkan model pembelajaran Snowball Throwing ini yang dilakukan secara berkelompok, maka guru diharuskan memberikan bimbingan terbatas pada siswa saat melakukan diskusi kelompok sehingga siswa benar-benar 
memanfaatkan waktu dan memahami materi dengan baik.

DAFTAR RUJUKAN

Arikunto, Suharsimi. 2008. Penelitian Tindakan Kelas. Jakarta: Bumi Aksara.

Depdiknas. 2001. Peraturan Menteri Pendidikan Nasional Nomor 22 tahun 2006 tentang Standar Isi untuk Satuan Pendidikan Dasar dan Menengah. Jakarta: Dikdasmen

Eveline, Nara. 2010. Teori Belajar dan Pembelajaran. Bogor: Ghalia Indonesia.

Gagne, R.M. 1977. Deconditioning of Learning. New York: Holt Rine Hart And Wiston.

Hidayati, dkk. 2008. Pengembangan Pendidikan IPS SD. Jakarta: Direktorat Jenderal Pendidikan Tinggi, Departemen Pendidikan Nasional.

Jarolimek, Jhon. 1977. Sosial Studies in Elementari Education. Macmilan, Publishing Co, Inc, New York.

Komalasari. 2010. Pembelajaran Kontekstual. Bandung: PT Refika Aditama.

Kunandar. 2008. Langkah Mudah Penelitian Tindakan Kelas,
Sebagai Pengembangan

Profesi Guru. Jakarta:

Rajawali Press.

Mudjiono, Dimyati. 2006. Belajar Dan Pembelajaran. Jakarta: Rineka Cipta.

Muhibbin, Syah. 1996. Psikologi Pendidikan suatu Pendekatan Baru. Bandung: Raja Remaja Rosda Karyal.

Sagala, Syaiful. 2009. Konsep dan Makna Pembelajaran. Bandung: Alfabeta.

Saminanto. 2010. Ayo Praktik PTK (Penelitian Tindakan Kelas). Semarang: Rasamai Media Group.

Sugiyono. 2007. Metode Penelitian Kuantitatif, Kuantitatif dan $R \& D$. Bandung: Alfabeta

Sujana. 2008. Dasar-dasar Proses Belajar Mengajar. Bandung: Sinar Baru

Syah, Muhibbin. 2010. Psikologi Pendidikan Dengan Pendekatan Baru. Bandung: Rosda

Trianto. 2009. Mendesain Model Pembelajaran InovatifProgresif. Jakarta: Kencana

Winkel, W.S. 1996. Psikologi Pengajaran. Jakarta: Gramedia. 